\title{
FGFR1/FGFR1OP Fusion Gene
}

National Cancer Institute

\section{Source}

National Cancer Institute. FGFR1/FGFR1OP Fusion Gene. NCI Thesaurus. Code C99694.

A fusion gene that results from a chromosomal translocation $t(6 ; 8)(q 27 ; p 11)$ that fuses intron 8 of the FGFR1 gene with intron 6, 7 or 8 of the FGFR1OP gene. This translocation is associated with 8p11 myeloproliferative disorder. 